\title{
Situational Position and Student Choice Criteria
}

\author{
H. JOHN CHURCH* and DAVID W. GILLINGHAM*
}

\section{ABSTRACT}

The student in choosing a particular university to attend does so within a particular university-student situational context. This paper demonstrates that the situational context significantly influences the evaluative criteria used by students in deciding which university to attend. Using a Canadian university as a case study, the authors develop an analytical framework for understanding the relationship between the particular university-student situational context and the student choice of university decision criteria.

\section{RÉSUMÉ}

Lorsqu'il(elle) choisit l'université où il(elle) va poursuivre ses études, l'étudian$t(e)$ prend en considération des facteurs relatifs à l'université et à sa situation en tant qu'étudiant(e). Cet article montre que le contexte d'une situation influence d'une façon significative les critères d'évaluation dont se servent les étudiants au cours de leur choix d'une université. Prenant une université canadienne comme exemple, les auteurs élaborent un cadre analytique qui permet de comprendre le rapport qui existe entre d'une part, le contexte de la situation particulière de l'université et de l'étudiant(e) et d'autre part, les critères dont se sert l'étudiant(e) lorqu'il(elle) choisit une université.

\section{INTRODUCTION}

The student in choosing to go on for a university education makes a number of decisions. Though the decisions and decision processes are highly interrelated, four of these decisions can be viewed as somewhat distinct. They are: (1) the decision of whether or not to seek a university education, (2) the decision of what type of studies the student will attempt to pursue, (3) the decision of which universities to apply to for admission, and (4) the final decision of which university to attend.

*John Church is an Associate Professor and David Gillingham is a Full Professor at Laurentian University. This research was funded by Laurentian University as a special project of Dr. F. Turner, Executive Vice-President. 
FIGURE 1

A Consumer Behavior Model of the Student's Selection for Admission of a First Choice University

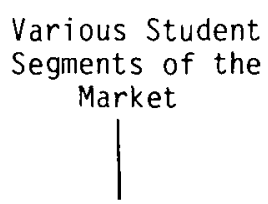

Evaluative Criteria Used by the Student in Deciding to which Universities to apply

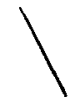

Decision of which

University to Select as

First Choice for Admission
University

Products

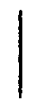

Student Evaluative

Ratings of the

various universities

on the selected

evaluative criteria

An earlier paper by Church and Gillingham (1983a), which concentrated on the first of these student decisions, provided an analysis of why students sought a university education. The research reported in this paper concentrates on the third of these decisions and in particular on the process which leads students to select a particular university as their first choice.

A general consumer behavior model which describes the focus of this research is presented as Figure 1.

Figure 1 proposes: (1) there exist various prospective university student segments (e.g. poor/not poor, young/old, academically strong/weak students); (2) each student segment may place differing importance on university evaluative factors (e.g. the university's reputation for the student's desired program of study, class size, advice of others); (3) the product of the importance placed on each evaluative factor by a student multiplied by the student's rating of each university on such evaluative factors (e.g. University A may be rated as having a very high reputation for the student's desired program of studies, whereas University B might have a much lower rating on this particular evaluative criteria) dictate his/her choice ranking of universities.

Dickson (1982) suggests that in many cases a full person-situation benefit segmentation may be appropriate when attempting to explain consumer behavior. Person-benefit segmentation is a technique for analyzing the consumer's behavior by looking first at the situation within which the consumer makes decisions and then at the benefits sought by each consumer group within each situation. 
Certainly, the student's choice process is one of high involvement where the person-effect is likely to be large. The authors concluded that although simple benefit segmentation was probably most appropriate in attempting to understand the student's decision process of whether or not to seek a university education, a situation-benefit segmentation was more appropriate when attempting to understand a student's process for selecting preferred universities for application. Moreover, as Dickson points out, the situation scenario studies of Sandell (1968) and Belk (1974) provide enough evidence for the inclusion of situation effects within the analytical framework for studying the student's decision-making process.

\section{SITUATIONS AFFECTING STUDENT CHOICE OF UNIVERSITY}

The student makes a choice of universities to which to apply within a situational context. One can view this situational context in a number of ways. For example, one can identify situational contexts simply as student situational contexts (e.g. financially concerned/not financially concerned students, high academic achievers/low academic achievers, young/old students). From a university management point of view, however, the examination of evaluative criteria employed by potential consumers within situational contexts which affect both the student and the university (i.e. university-student situational contexts) would seem to offer the greatest potential for university officers to recognize ways by which to increase the number of students choosing their particular university as their first choice.

There are several university-student situational contexts which can be identified. These include university-student proximity, university availability of the student's desired program of study, university availability of the student's desired program of study in the student's desired language of instruction.

This paper examines student evaluative criteria and first choice of university within two of these university-student situational contexts: (1) university-student proximity, and (2) university availability of student's desired program of study.

Proximity is a measure of the closeness of a given university to the student making the university application selection. Proximity is essentially a noncontrollable environmental variable although new technology is beginning to change this with the advent of more advanced and effective distance learning systems. The proximity situational context was chosen by the authors for investigation because it was expected to have a major influence on the evaluative criteria employed and also precisely because of its non-controllable nature. From a university officer's perspective, the officer's interest in understanding the impact a non-controllable situational context (such as proximity) has on the evaluative criteria employed by potential consumers, is for the purpose of determining the most pertinent information to supply to relevant potential consumer groups so as to increase the consumer's rating of the university on the criteria being employed, and thus hopefully the frequency with which that university is chosen as first 
choice. Thus, administrators use such understanding primarily to help them design effective promotional messages, rather than as a means for altering the university-student situational context or the potential consumer's evaluative criteria.

Availability of the student's desired program of study is the perceived availability of the program within the university system. Like proximity, perceived program availability within the total university system is not under the control of a particular university but, unlike proximity, within certain limits the management of a particular university can choose whether or not to offer programs that are available at other institutions, or whether or not to offer programs that are unique. In this instance, university officers are interested in understanding the impact a partially-controllable situational context (such as perceived program availability) has on the evaluative criteria employed by prospective consumers, for both university program planning purposes and as an aid to effective communications with potential consumers.

Thus, this study attempts to examine the evaluative criteria used by students in determining where to apply in each of four university-student situational contexts:

i. those who perceive their desired program of study as widely available and who are considering attending the closest university;

ii. those who perceive their desired program of study as widely available and who are considering attending a university other than their closest university;

iii. those who perceive their desired program of study as not widely available and who are considering attending the closest university;

iv. those who perceive their desired program of study as not widely available and who are considering attending a university other than their closest university.

\section{EVALUATIVE CRITERIA}

Watts (1972) provides an excellent review of the literature on educational choice process although the results from his own model, using mainly sociological inputs, were inconclusive. He did conclude that the evidence suggests that choices are often made in a very random way. Whilst this may indeed appear to be the case, it is not a satisfactory answer for serious investigators of consumer behavior. Watts' study did however provide the authors with a number of major evaluative criteria likely to be used by students. Additionally, a number of other researchers have investigated the university choice process. A review of this literature and in particular the work of Lynch and Hooley (1980), Punj and Staelin (1978), Saunders and Lancaster (1980), and Vaughn et al. (1978) led the authors to a list of possible evaluative criteria that students use in selecting a university.

\section{THE STUDY}

A questionnaire was developed to gather information on the student, the factors the student considered important when deciding where to apply for university admission, the student's rating of each university to which he applied on each of 
these factors, and the student's overall choice preference of each university applied to. Special care was taken to include questions directly relating to university proximity at time of application and perceived program availability, the above mentioned situational variables.

The questionnaire was administered to a sample of first year classes covering all subject areas taught at Laurentian University' ${ }^{1}$. A total of 517 students completed the questionnaire which, after adjusting for incomplete information, left 438 available for this stage of the analysis.

The important evaluative factor component of this questionnaire consisted of a series of 18 questions, using a five point importance rating scale for each evaluative factor. A further series of questions asked the respondent to rank his/her first preference university on a seven point rating scale for each of the 18 factors. The combination of each student's factor importance rating times the student's first choice university's rating on that factor provides a 35 point scale of the relative importance of each factor for the student's first choice university. The results from the investigation of using this multiplicative 35 point scale over the 18 factors, together with the responses to a small set of demographic questions, provides the data base for the analyses which follow.

\section{LAURENTIAN UNIVERSITY}

Laurentian, a small university, founded in 1960, is located in Sudbury, Northern Ontario. The closest universities to Laurentian are in Toronto, some 370 kilometers to the South, and in Ottawa, over 500 kilometers to the East. Laurentian offers a wide range of programs but does not offer Medicine or Law. It does offer a good selection of programs and courses in the Humanities, Social Sciences, Sciences and the Professional Schools.

The population of the area served by Laurentian is about 500,000 people scattered over a vast area of Northeastern Ontario. About thirty percent of the population is francophone and Laurentian is officially a bilingual university.

The study presented in this paper was conducted at Laurentian in part because the authors felt it would offer a good test of the situational framework previously described. In particular, Laurentian offers a good mix of widely available and not so widely available programs (e.g. Translation and Interpretation, Sports Administration, and Social Work). At the same time, Laurentian attracts a significant proportion of its students from outside its drawing region.

\section{THE STUDY'S RESULTS}

\section{Absolute Importance of the Evaluative Factors for Each Situational Context}

In order to test whether the student-university proximity, program-availability situational framework was useful, the evaluative factor relative importance data was analyzed for each situational group by whether or not Laurentian was chosen as first choice. Table 1 presents the mean scores for each of the 18 evaluative factors measured by situational group for those students who chose Laurentian as 
TABLE 1

Mean Factor Scores by Situational Group for Laurentian 1st Choice

\begin{tabular}{|c|c|c|c|c|}
\hline \multirow{3}{*}{$\begin{array}{l}\text { Mean scores for } \\
\text { each situational } \\
\text { group on combined } \\
\text { importance times } \\
\text { ranking scale ( } 1 \\
\text { to } 35,1 \text { exception- } \\
\text { ally important, } 35 \\
\text { least important) }\end{array}$} & \multicolumn{4}{|c|}{ Situational Groups } \\
\hline & \multicolumn{2}{|c|}{$\begin{array}{l}\text { Program perceived as } \\
\text { widely available }\end{array}$} & \multicolumn{2}{|c|}{$\begin{array}{l}\text { Program perceived as } \\
\text { not widely available }\end{array}$} \\
\hline & $\begin{array}{l}\text { Laurentian } \\
\text { closest } \\
\text { Col. } 1\end{array}$ & $\begin{array}{l}\text { Laurentian } \\
\text { not closest } \\
\text { Col. } 2\end{array}$ & $\begin{array}{l}\text { Laurentian } \\
\text { closest } \\
\text { Col. } 3\end{array}$ & $\begin{array}{l}\text { Laurentian } \\
\text { not closest } \\
\text { Col. } 4\end{array}$ \\
\hline
\end{tabular}

Evaluative Factors (Scale 1 to 35 , NOTE: LOW VALUES = HIGH IMPORTANCE)

\begin{tabular}{|c|c|c|c|c|}
\hline $\begin{array}{l}\text { Academic quality of } \\
\text { desired program }\end{array}$ & 8.6 & 10.6 & 4.1 & 4.0 \\
\hline $\begin{array}{l}\text { University's repu- } \\
\text { tation for program }\end{array}$ & 9.2 & 10.7 & 6.4 & 4.0 \\
\hline $\begin{array}{l}\text { Likel ihood of admis- } \\
\text { sion to program }\end{array}$ & 7.1 & 11.7 & 5.3 & 8.9 \\
\hline $\begin{array}{l}\text { Importance of inst- } \\
\text { ructional language }\end{array}$ & 7.5 & 11.7 & 4.4 & 7.0 \\
\hline Class size & 6.1 & 7.9 & 3.3 & 4.7 \\
\hline Advice of others & 13.4 & 12.4 & 8.4 & 9.6 \\
\hline $\begin{array}{l}\text { Cost of attending } \\
\text { university }\end{array}$ & 9.1 & 15.1 & 6.5 & 14.4 \\
\hline $\begin{array}{l}\text { Likel ihood of fin- } \\
\text { ancial assistance }\end{array}$ & 16.0 & 20.7 & 14.2 & 15.6 \\
\hline $\begin{array}{l}\text { Residence availa- } \\
\text { bility \& quality }\end{array}$ & 17.8 & 8.5 & 11.9 & 8.5 \\
\hline $\begin{array}{l}\text { Overall university } \\
\text { academic quality }\end{array}$ & 11.3 & 13.6 & 8.7 & 9.4 \\
\hline $\begin{array}{l}\text { Overall university } \\
\text { reputation }\end{array}$ & 11.1 & 14.2 & 10.2 & 10.2 \\
\hline $\begin{array}{l}\text { University acceptance } \\
\text { likelihood }\end{array}$ & 6.2 & 10.0 & 4.9 & 7.8 \\
\hline $\begin{array}{l}\text { Location suitability } \\
\text { (excluding costs) }\end{array}$ & 5.1 & 13.8 & 3.1 & 15.3 \\
\hline Size of University & 7.4 & 9.2 & 3.9 & 5.4 \\
\hline $\begin{array}{l}\text { Likelihood of meet- } \\
\text { ing new people }\end{array}$ & 14.0 & 12.6 & 11.1 & 9.7 \\
\hline $\begin{array}{l}\text { Desire to attend } \\
\text { with others }\end{array}$ & 16.6 & 21.5 & 14.6 & 23.1 \\
\hline $\begin{array}{l}\text { Athletic facility } \\
\text { quality }\end{array}$ & 13.0 & 11.1 & 13.1 & 9.6 \\
\hline Social atmosphere & 13.3 & 10.8 & 11.7 & 10.3 \\
\hline \multicolumn{5}{|c|}{ Demographics (Scale as indicated) } \\
\hline $\operatorname{Sex}(M=1, F=2)$ & 1.4 & 1.4 & 1.7 & 1.5 \\
\hline $\begin{aligned} & \text { Age }(17-21=1 \\
&7=65 \text { plus })\end{aligned}$ & 1.2 & 1.3 & 1.2 & 1.0 \\
\hline $\begin{array}{l}\text { Marital Status } \\
\quad(M=1, S=2)\end{array}$ & 2.0 & 2.0 & 1.9 & 2.0 \\
\hline $\begin{array}{l}\text { Highschool grades } \\
(\langle 60=1,>90=8)\end{array}$ & 3.9 & 3.9 & 4.0 & 4.5 \\
\hline $\begin{array}{l}\text { Language spoken } \\
\quad(\mathrm{E} n \mathrm{l} l=1, \mathrm{Fr}=2)\end{array}$ & 1.4 & 1.5 & 1.4 & 1.1 \\
\hline $\begin{array}{l}\text { \# of Complete responses } \\
\text { in group }\end{array}$ & 84 & 34 & 60 & 66 \\
\hline
\end{tabular}

their first choice for admission. This table covers the responses of 244 first year students; another 194 students responded in full but chose another university as their first choice for admission. Table 1 also presents information on the respondent groups' sex, age, marital status, highschool grades and language. 
TABLE 2

Ranking of Factors by Situational Group for Laurentian 1st Choice

\begin{tabular}{|c|c|c|c|c|}
\hline \multirow{3}{*}{$\begin{array}{l}\text { Relative Ranking of the } \\
\text { eighteen evaluative } \\
\text { factors for each } \\
\text { situational group on } \\
\text { a } 1 \text { to } 18 \text { scale where } \\
\text { I equals the most } \\
\text { important factor }\end{array}$} & \multicolumn{4}{|c|}{ Situational Groups } \\
\hline & \multicolumn{2}{|c|}{$\begin{array}{l}\text { Program perceived as } \\
\text { widely available }\end{array}$} & \multicolumn{2}{|c|}{$\begin{array}{l}\text { Program perceived as } \\
\text { not widely available }\end{array}$} \\
\hline & $\begin{array}{l}\text { Laurentian } \\
\text { closest } \\
\text { Col. } 1\end{array}$ & $\begin{array}{l}\text { Laurentian } \\
\text { not closest } \\
\text { Col. } 2\end{array}$ & $\begin{array}{l}\text { Laurentian } \\
\text { closest } \\
\text { Col. } 3\end{array}$ & $\begin{array}{l}\text { Laurentian } \\
\text { not closest } \\
\text { Col. } 4\end{array}$ \\
\hline Evaluative Factors (Scal & le 1 to 18 , & NOTE: LOW VA & ALUES $=\mathrm{HIGH}$ & IMPOR (ANCE) \\
\hline $\begin{array}{l}\text { Academic quality of } \\
\text { desired program }\end{array}$ & 7 & 5 & 4 & 1 \\
\hline $\begin{array}{l}\text { University's repu- } \\
\text { tation for program }\end{array}$ & 9 & 6 & 8 & 1 \\
\hline $\begin{array}{l}\text { Likel ihood of admis- } \\
\text { sion to program }\end{array}$ & 4 & 9 & 7 & 8 \\
\hline $\begin{array}{l}\text { Importance of inst- } \\
\text { ructional language }\end{array}$ & 6 & 9 & 5 & 5 \\
\hline Class size & 2 & 1 & 2 & 3 \\
\hline Advice of others & 14 & 11 & 10 & 10 \\
\hline $\begin{array}{c}\text { Cost of attending } \\
\text { university }\end{array}$ & 8 & 16 & 9 & 15 \\
\hline $\begin{array}{l}\text { Likel ihood of fin- } \\
\text { ancial assistance }\end{array}$ & 16 & 17 & 17 & 17 \\
\hline $\begin{array}{l}\text { Residence availa- } \\
\text { bility \& quality }\end{array}$ & 18 & 2 & 15 & 7 \\
\hline $\begin{array}{l}\text { Overall university } \\
\text { academic quality }\end{array}$ & 11 & 13 & 11 & 9 \\
\hline $\begin{array}{l}\text { Overall university } \\
\text { reputation }\end{array}$ & 10 & 15 & 12 & 13 \\
\hline $\begin{array}{l}\text { University acceptance } \\
\text { likelihood }\end{array}$ & 3 & 4 & 6 & 6 \\
\hline $\begin{array}{l}\text { Location suitability } \\
\text { (excluding costs) }\end{array}$ & 1 & 14 & 1 & 16 \\
\hline Size of University & 5 & 3 & 3 & 4 \\
\hline $\begin{array}{l}\text { Likel ihood of meet- } \\
\text { ing new people }\end{array}$ & 15 & 12 & 13 & 12 \\
\hline $\begin{array}{l}\text { Desire to attend } \\
\text { with others }\end{array}$ & 17 & 18 & 18 & 18 \\
\hline $\begin{array}{l}\text { Athletic facility } \\
\text { quality }\end{array}$ & 12 & 8 & 16 & 10 \\
\hline Social atmosphere & 13 & 7 & 14 & 14 \\
\hline
\end{tabular}

Table 1 indicates that students, who perceive their desired program of studies as not widely available (in comparison to those who perceive their desired program of study as widely available), place more importance on a wide range of evaluative factors in determining a first choice university. For example, Table 1 shows that they place more importance on the academic quality of their desired program (4.1 and 4.0 as compared to 8.6 and 10.6 , where low numbers indicate high importance). In fact, they place more importance on all but three factors: location suitability (excluding costs), desire to attend with others, and athletic facility quality. On the other hand, students who perceive their desired program of study as widely available cannot be said to place more importance on any of the 18 evaluative factors. 
Students who perceive their desired program of study as not widely available are also more likely to be women (though this may be somewhat incidental). They also tend to have higher school grades, especially for that group who are not attending their closest university.

Those who live closest to their first choice university (Columns 1 and 3 of Table 1) in comparison to those who don't (Columns 2 and 4 of Table 1) also tend to place more importance on a wide range of evaluative factors. In this case, such students tend to place more importance on the following factors: location suitability (excluding costs), cost of attending, likelihood of admission to desired program of study, university acceptance likelihood, importance of instructional language. They also place more importance, but to a lesser degree, on: class size, university size, desire to attend with others, likelihood of financial assistance and overall university academic quality.

On the other hand, those whose first choice university is not their closest university tend to place more importance on residence quality and availability and, to a lesser extent, on three other factors: social atmosphere, the likelihood of meeting new people, and athletic facility quality.

\section{Relative Importance of Evaluative Factors for Each Situational Context}

Given a particular situational context, administrators are perhaps less concerned with the absolute importance than with the relative importance placed on these evaluative factors by students. In this context, Table 2 ranks the eighteen evaluative factors employed by each situational group. These findings are discussed below for each situational context.

Situational Context 1 - Those who perceive their desired program of study as widely available and whose first choice is to attend closest university (Column 1 of Table 2).

Students in this group tend to place importance on, in descending order, the following 9 (the top half) factors: location suitability, class size, university acceptance likelihood, likelihood of admission to desired program, size of university, instructional language, academic quality of desired program, cost of attending university, and the university's reputation for program.

Situational Context 2 - Those who perceive their desired program of study as widely available and whose first choice is to attend a university other than their closest university.

Students in this situational context tend to place importance on quite different factors. Class size is the most important factor as compared to being the second or third most important factor for other situational groups. It is followed closely by residence availability and quality whose relative importance is unique to this group. Location suitability (excluding costs) which was the most important factor for group 1 students is the 14th most important factor for this situational group. The cost of attending university drops from the 8th place to 16th. Furthermore, relatively more importance is placed on program quality and reputation, on university size and on other unique factors such as social atmosphere and athletic 
TABLE 3

Mean Factor Scores by Situational Group for Other Univ. 1st Choice

\begin{tabular}{|c|c|c|c|c|}
\hline \multirow{3}{*}{$\begin{array}{l}\text { Mean scores for } \\
\text { each situational } \\
\text { group on combined } \\
\text { importance times } \\
\text { ranking scale ( } 1 \\
\text { to } 35, \text { l exception- } \\
\text { ally important, } 35 \\
\text { least important) }\end{array}$} & \multicolumn{4}{|c|}{ Situational Groups } \\
\hline & $\begin{array}{l}\text { Program pe } \\
\text { widely }\end{array}$ & $\begin{array}{l}\text { rceived as } \\
\text { vailable }\end{array}$ & $\begin{array}{l}\text { Program pe } \\
\text { not widely }\end{array}$ & $\begin{array}{l}\text { ceived as } \\
\text { available }\end{array}$ \\
\hline & $\begin{array}{l}\text { Laurentian } \\
\text { not closest } \\
\text { Co1. } 1\end{array}$ & $\begin{array}{l}\text { Laurentian } \\
\text { closest } \\
\text { Col. } 2\end{array}$ & $\begin{array}{l}\text { Laurentian } \\
\text { not closest } \\
\text { Col. } 3\end{array}$ & $\begin{array}{l}\text { Laurentian } \\
\text { closest } \\
\text { Col. } 4\end{array}$ \\
\hline
\end{tabular}

Evaluative Factors (Scale 1 to 35 , NOTE: LOW VALUES $=$ HIGH IMPORTANCE)

\begin{tabular}{|c|c|c|c|c|}
\hline $\begin{array}{l}\text { Academic quality of } \\
\text { desired program }\end{array}$ & 9.3 & 5.6 & 3.7 & 3.3 \\
\hline $\begin{array}{l}\text { University's repu- } \\
\text { tation for program }\end{array}$ & 8.9 & 6.7 & 4.7 & 3.6 \\
\hline $\begin{array}{l}\text { Likelihood of admis- } \\
\text { sion to program }\end{array}$ & 9.6 & 11.5 & 9.3 & 8.8 \\
\hline $\begin{array}{l}\text { Importance of inst- } \\
\text { ructional language }\end{array}$ & 7.9 & 9.3 & 5.8 & 5.7 \\
\hline Class size & 10.3 & 10.1 & 10.2 & 9.1 \\
\hline Advice of others & 12.1 & 9.8 & 9.8 & 8.7 \\
\hline $\begin{array}{l}\text { Cost of attending } \\
\text { university }\end{array}$ & 14.4 & 16.5 & 12.6 & 17.6 \\
\hline $\begin{array}{l}\text { Likelihood of fin- } \\
\text { ancial assistance }\end{array}$ & 17.8 & 17.6 & 19.5 & 15.4 \\
\hline $\begin{array}{l}\text { Residence availa- } \\
\text { bility \& quality }\end{array}$ & 10.1 & 10.2 & 10.4 & 10.0 \\
\hline $\begin{array}{l}\text { Overall university } \\
\text { academic quality }\end{array}$ & 8.8 & 6.6 & 4.7 & 5.0 \\
\hline $\begin{array}{l}\text { Overall university } \\
\text { reputation }\end{array}$ & 8.3 & 6.5 & 4.8 & 5.3 \\
\hline $\begin{array}{l}\text { University acceptance } \\
\text { likelihood }\end{array}$ & 9.9 & 11.0 & 9.2 & 10.3 \\
\hline $\begin{array}{l}\text { Location suitability } \\
\text { (excluding costs) }\end{array}$ & 9.5 & 11.2 & 10.5 & 14.1 \\
\hline Size of University & 10.5 & 11.1 & 10.8 & 10.1 \\
\hline $\begin{array}{l}\text { Likelihood of meet- } \\
\text { ing new people }\end{array}$ & 11.5 & 9.9 & 11.4 & 9.1 \\
\hline $\begin{array}{l}\text { Desire to attend } \\
\text { with others }\end{array}$ & 13.0 & 13.7 & 12.9 & 18.3 \\
\hline $\begin{array}{l}\text { Athletic facility } \\
\text { quality }\end{array}$ & 11.4 & 12.8 & 12.4 & 13.5 \\
\hline Social atmosphere & 10.7 & 10.3 & 12.1 & 10.2 \\
\hline Demographics (Scale as & ated) & & & \\
\hline $\operatorname{Sex}(M=1, F=2)$ & 1.3 & 1.4 & 1.3 & 1.6 \\
\hline $\begin{array}{l}\text { Age }(17-21=1 \\
7=65 \text { plus })\end{array}$ & 1.3 & 1.1 & 1.2 & 1.0 \\
\hline $\begin{array}{l}\text { Marital Status } \\
\qquad(M=1, S=2)\end{array}$ & 2.0 & 1.9 & 2.0 & 2.0 \\
\hline $\begin{array}{l}\text { Highschool grades } \\
\qquad(\langle 60=1,>90=8)\end{array}$ & 3.8 & 3.5 & 4.2 & 4.1 \\
\hline $\begin{array}{l}\text { Language spoken } \\
\qquad(E n g l=1, F r=2)\end{array}$ & 1.4 & 1.1 & 1.5 & 1.1 \\
\hline $\begin{array}{l}\text { \# of Complete responses } \\
\text { in group }\end{array}$ & 47 & 36 & 57 & 54 \\
\hline
\end{tabular}

facility quality; much less importance is placed upon program admission likelihood but not on university admission likelihood.

Situational Context 3 - Those who perceive their desired program of study as not widely available and whose first choice is to attend closest university. 
TABLE 4

Ranking of Factors by Situational Group for Other Univ. 1st Choice

\begin{tabular}{|c|c|c|c|c|}
\hline \multirow{3}{*}{$\begin{array}{l}\text { Relative Ranking of the } \\
\text { eighteen evaluative } \\
\text { factors for each } \\
\text { situational group on } \\
\text { a l to } 18 \text { scale where } \\
\text { l equals the most } \\
\text { important factor }\end{array}$} & \multicolumn{4}{|c|}{ Situational Groups } \\
\hline & \multicolumn{2}{|c|}{$\begin{array}{l}\text { Program perceived as } \\
\text { widely available }\end{array}$} & \multicolumn{2}{|c|}{$\begin{array}{l}\text { Program perceived as } \\
\text { not widely available }\end{array}$} \\
\hline & $\begin{array}{l}\text { Laurentian } \\
\text { not closest } \\
\text { Col. } 1\end{array}$ & $\begin{array}{l}\text { Laurentian } \\
\text { closest } \\
\text { Col. } 2\end{array}$ & $\begin{array}{l}\text { Laurentian } \\
\text { not closest } \\
\text { Col. } 3\end{array}$ & $\begin{array}{l}\text { Laurentian } \\
\text { closest } \\
\text { Col. } 4\end{array}$ \\
\hline \multicolumn{3}{|c|}{ Evaluative Factors (Scale 1 to 18 , NOTE } & ALUES $=\mathrm{HIGH}$ & IMPORTANCE \\
\hline $\begin{array}{l}\text { Academic quality of } \\
\text { desired proqram }\end{array}$ & 5 & 1 & 1 & 1 \\
\hline $\begin{array}{l}\text { University's repu- } \\
\text { tation for program }\end{array}$ & 4 & 4 & 2 & 2 \\
\hline $\begin{array}{l}\text { Likelihood of admis- } \\
\text { sion to program }\end{array}$ & 7 & 14 & 7 & 7 \\
\hline $\begin{array}{l}\text { Importance of inst- } \\
\text { ructional language }\end{array}$ & 1 & 5 & 5 & 5 \\
\hline Class size & 10 & 8 & 9 & 8 \\
\hline Advice of others & 15 & 6 & 8 & 6 \\
\hline $\begin{array}{l}\text { Cost of attending } \\
\text { university }\end{array}$ & 17 & 17 & 16 & 17 \\
\hline $\begin{array}{l}\text { Likelihood of fin- } \\
\text { ancial assistance }\end{array}$ & 18 & 18 & 18 & 16 \\
\hline $\begin{array}{l}\text { Residence availa- } \\
\text { bility \& quality }\end{array}$ & 9 & 9 & 10 & 10 \\
\hline $\begin{array}{l}\text { Overall university } \\
\text { academic quality }\end{array}$ & 3 & 3 & 2 & 3 \\
\hline $\begin{array}{l}\text { Overall university } \\
\text { reputation }\end{array}$ & 2 & 2 & 4 & 4 \\
\hline $\begin{array}{l}\text { University acceptance } \\
\text { likelihood }\end{array}$ & 8 & 11 & 6 & 13 \\
\hline $\begin{array}{l}\text { Location suitability } \\
\text { (excluding costs) }\end{array}$ & 6 & 13 & 11 & 15 \\
\hline Size of University & 11 & 12 & 12 & 11 \\
\hline $\begin{array}{l}\text { Likelihood of meet- } \\
\text { ing new people }\end{array}$ & 14 & 7 & 13 & 8 \\
\hline $\begin{array}{l}\text { Desire to attend } \\
\text { with others }\end{array}$ & 16 & 16 & 17 & 18 \\
\hline $\begin{array}{l}\text { Athletic facility } \\
\text { quality }\end{array}$ & 13 & 15 & 15 & 14 \\
\hline Social atmosphere & 12 & 10 & 14 & 12 \\
\hline
\end{tabular}

Students in this situational context are very similar to those in group 1, placing most importance on location suitability (excluding costs) and class size. The only difference is that they tend to place relatively greater importance on desired program quality and less relative importance on program and university admission likelihood.

Situational Context 4 - Those who perceive their desired program of study as not widely available and whose first choise is to attend a university other than their closest university.

Students in this situational context place very differing relative importance on evaluative factors compared with all other groups. For these students, program academic quality and program reputation are the most important factors. Otherwise, this group places emphasis on factors reasonably similar to those of 
group 2, with the exception that somewhat less relative importance is placed on residence availability and quality and on social atmosphere, and somewhat greater relative importance is placed on instructional language and on overall university academic quality.

Table 2 and its interpretation provide a description of the similarities and differences placed upon evaluative factors between the four availability-proximity situational groups. Whilst statistical testing of the differences is difficult, nevertheless, Kendal's Coefficient of Rank Concordance was calculated for the nine evaluative factors which were most important overall. This test indicated that there was no statistically significant correlation between the four groups; thus, the absence of correlation shows that these four groups are quite distinct in terms of the importance each places on various evaluative factors.

\section{EXTENSION OF THE AVAILABILITY - PROXIMITY SITUATIONAL FRAMEWORK}

Tables 1 and 2, previously described, pertained to those students who selected Laurentian as first choice. Similar analyses were performed for those students who chose any other university as first choice and are presented as Tables 3 and 4 .

Note, the headings of Table 3 have been rearranged so that Table 3 can be compared directly (column by column) with Table 1 . Thus, the second column of Table 3 indicates the importance of evaluative factors for that situational group whose first choice university (any university other than Laurentian) is not the closest university (since Laurentian is the closest), which is equivalent to the second column of Table 1 which pertains also to a situational group whose first choice university (Laurentian) is not the closest university (Laurentian not closest).

With some minor exceptions, the interpretation of Table 3 is similar to the previous discussion of Table 1, and thus will not be repeated here.

Table 4 which indicates the relative ranking of importance of the 18 evaluative factors by situational group, does however show marked contrast with Table 2 .

For all four situational groups, students selecting Laurentian as first choice (Table 2), compared with those choosing any other university as first choice (Table 4) tend to place, relatively:

i far more importance on class size and on university size;

ii somewhat more importance on university acceptance likelihood, and

iii far less importance on the university's overall academic quality and overall university reputation.

Whilst not surprising these findings lend credibility to the results. Laurentian is known, and indeed promotes, its small size and its smaller class sizes. On the other hand, being a relatively new and smaller institution, it does not have a strong reputation overall nor is it likely to be perceived as having relatively high academic quality standards. Additionally, Laurentian operates far fewer limited enrollment programs than its major competitors in Ontario. 
In addition, those choosing Laurentian as first choice (as compared to those who choose any other university as first choice) downplay the relative importance of academic quality of desired program and university's reputation for student's desired program of studies in all situations except where the program is perceived as not widely available and where the student's first choice is not the closest university.

For programs which are perceived as widely available, those choosing Laurentian as first choice (as compared to those who choose any other university as first choice) place greater relative importance on likelihood of admission to program but place less relative importance on instructional language.

Regardless of program availability perception, those living closest to Laurentian and choosing Laurentian as first choice (as compared with those not living closest to Laurentian and choosing any other university as first choice) place greater relative importance on cost of attending university and the university's location suitability (excluding costs) ${ }^{2}$; while those not living closest to Laurentian but choosing Laurentian as first choice (as compared to those living closest to Laurentian but choosing any other university as first choice) place greater relative importance on residence availability and athletic facility quality while downplaying the relative importance of the likelihood of meeting new people.

\section{THE PREDICTION OF A STUDENT'S FIRST CHOICE UNIVERSITY}

A second purpose of this paper was to determine whether it was possible to predict a student's first choice university given information on the student's proximity to various universities, whether his desired program of studies was perceived as widely available or not, and given within this context information on the importance of various evaluative factors to the student.

Given the data limitations, it was decided to concentrate on the development of a model which would predict whether a student's first choice university was either Laurentian or any other university.

Actually, four predictive models were developed, one for each of the following situations:

i. where the student's desired program of study is perceived as widely available and Laurentian is the student's closest university;

ii. where the student's desired program of study is perceived as widely available and the student resides closest to some other university than Laurentian;

iii. where the student's desired program of study is perceived as not widely available and Laurentian is the student's closest university;

iv. where the student's desired program of study is perceived as not widely available and the student resides closest to some other university than Laurentian.

Note, in all cases the student has decided to apply to at least one university and must determine which of these universities would be his/her first preference. The situations presented above are similar yet quite different from the availability proximity situational contexts previously discussed. Consider the first situation for 
TABLE 5

Standardized Discriminant Function Coefficients, Discriminating between Laurentian First Choice and Any Other University as First Choice - Wilks Method

\begin{tabular}{|c|c|c|c|c|}
\hline \multirow[b]{3}{*}{$\begin{array}{l}\text { Discriminant } \\
\text { Model Number }\end{array}$} & \multicolumn{4}{|c|}{ Situational Groups } \\
\hline & \multicolumn{2}{|c|}{$\begin{array}{l}\text { Program perceived as } \\
\text { widely available }\end{array}$} & \multicolumn{2}{|c|}{$\begin{array}{l}\text { Program perceived as } \\
\text { not widely available }\end{array}$} \\
\hline & $\begin{array}{l}\text { Laurentian } \\
\text { closest } \\
\# 1\end{array}$ & $\begin{array}{l}\text { Laurentian } \\
\text { not closest } \\
\# 2\end{array}$ & $\begin{array}{l}\text { Laurentian } \\
\text { closest } \\
\# 3\end{array}$ & 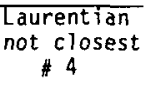 \\
\hline $\begin{array}{l}\text { Academic quality } \\
\text { of desired prog } \\
\text { University's repu- }\end{array}$ & & & & \\
\hline $\begin{array}{l}\text { tation for prog } \\
\text { Likelihood of admis- } \\
\text { sion to program }\end{array}$ & & & -0.245 & \\
\hline $\begin{array}{l}\text { Importance of inst- } \\
\text { ructional lang }\end{array}$ & & 1.135 & & \\
\hline Class size & & -1.913 & -0.374 & -0.568 \\
\hline Advice of others & & & & -0.543 \\
\hline $\begin{array}{l}\text { Cost of attending } \\
\text { university } \\
\text { Likelihood of fin- } \\
\text { ancial assist }\end{array}$ & & -0.375 & -0.409 & -0.355 \\
\hline $\begin{array}{l}\text { Residence availa- } \\
\text { bility \& quality }\end{array}$ & 0.357 & -0.438 & 0.691 & \\
\hline $\begin{array}{l}\text { 0verall university } \\
\text { academic quality }\end{array}$ & & & & 0.675 \\
\hline $\begin{array}{l}\text { Overall university } \\
\text { reputation }\end{array}$ & 0.700 & 0.916 & 0.655 & \\
\hline $\begin{array}{l}\text { Univ. acceptance } \\
\text { likel ihood }\end{array}$ & -0.556 & -0.399 & & -0.287 \\
\hline $\begin{array}{l}\text { Location suitabil- } \\
\text { ity (excl. costs) }\end{array}$ & -0.488 & 0.333 & -0.449 & 0.290 \\
\hline Size of University & -0.458 & 1.193 & -0.330 & \\
\hline $\begin{array}{l}\text { Likelihood of meet- } \\
\text { ing new people }\end{array}$ & & 0.918 & & -0.374 \\
\hline $\begin{array}{l}\text { Desire to attend } \\
\text { with others }\end{array}$ & & & -0.402 & 1.146 \\
\hline $\begin{array}{l}\text { Athletic facility } \\
\text { quality }\end{array}$ & -0.374 & & & -0.224 \\
\hline Social atmosphere & & -0.874 & & \\
\hline $\operatorname{Sex}(M=1, F=2)$ & & & & 0.316 \\
\hline $\begin{aligned} \text { Age } & (17-21=1 \\
7 & =65 \text { plus })\end{aligned}$ & 0.305 & -0.691 & 0.397 & \\
\hline $\begin{array}{l}\text { Marital Status } \\
\qquad(M=1, S=2)\end{array}$ & 0.391 & & & 0.349 \\
\hline $\begin{array}{l}\text { Highschool grades } \\
(\langle 60=1,>90=8)\end{array}$ & & 0.616 & 0.267 & -0.228 \\
\hline $\begin{array}{l}\text { Language spoken } \\
\qquad(\text { Engl }=1, F r=2)\end{array}$ & 0.556 & & & \\
\hline $\begin{array}{l}\text { Group Centroids: } \\
\text { Laur. lst choice } \\
\text { Other lst choice }\end{array}$ & $\begin{array}{r}1.092 \\
-1.737\end{array}$ & $\begin{array}{r}1.530 \\
-1.238\end{array}$ & $\begin{array}{r}1.763 \\
-1.873\end{array}$ & $\begin{array}{r}1.335 \\
-1.535\end{array}$ \\
\hline
\end{tabular}




\begin{tabular}{|c|c|c|}
\hline \multicolumn{3}{|c|}{$\begin{array}{l}\text { Discriminant Models Prediction Accuracy (Percent of } \\
\text { respondents first choice universities correctly } \\
\text { predicted) }\end{array}$} \\
\hline \multirow{2}{*}{$\begin{array}{l}\text { Program Choice } \\
\text { Availability }\end{array}$} & \multicolumn{2}{|c|}{ University Choice Proximity } \\
\hline & $\begin{array}{l}\text { Laurentian } \\
\text { closest } \\
\text { university }\end{array}$ & $\begin{array}{l}\text { Laurentian } \\
\text { not closest } \\
\text { university }\end{array}$ \\
\hline $\begin{array}{l}\text { Program } \\
\text { perceived as } \\
\text { widely available }\end{array}$ & $89.2 \%$ & $70.4 \%$ \\
\hline $\begin{array}{l}\text { Program } \\
\text { perceived as } \\
\text { not widely } \\
\text { available }\end{array}$ & $89.5 \%$ & $89.4 \%$ \\
\hline
\end{tabular}

instance. Here the student, seeking admission for a widely available program, must select as his/her first preference university either Laurentian which is his/her closest university or any other university which is not his/her closest university. Recall that the availability - proximity situational context was a student university context and given that the student is choosing between two universities of which one is located closest to him/her, the student becomes a part of two different proximity situational contexts and in selecting one university over the other can be expected to place greater importance on evaluative factors pertinent to that situational context.

For each of the four situations, a discriminant analysis was performed in an attempt to determine which evaluative factors or demographic factors were most important in discriminating between those who chose Laurentian as first choice and those who chose any other university as first choice.

Table 5 provides for each of the four situation combinations the standardized discriminant function coefficients for a discriminant analysis for Laurentian as first choice against another university as first choice. The Wilks stepwise method was used.

The four models (as represented by each column of Table 5), resulting from the application of discriminant analysis, are much as one might expect given the conclusions drawn from the availability - proximity situational position analyses (Tables 1 through 4). For example, in each model the importance a student places upon overall university reputation (Models 1, 2 and 3) or quality (Model 4) shows a strong and consistent discriminating ability between those who chose Laurentian as first choice and those who chose any other university as first choice; with those who place high importance on overall university quality or reputation tending to 
TABLE 7

Discriminant Models Prediction Accuracy (Percent of
respondents first choice universities correctly
predicted)- Using only Cases with Missing Data
Which Were not Used for Building the Discriminant
Models

\begin{tabular}{lll}
\hline $\begin{array}{l}\text { Program Choice } \\
\text { Availability }\end{array}$ & \multicolumn{2}{c}{ University Choice Proximity } \\
\cline { 2 - 3 } & $\begin{array}{c}\text { Laurentian } \\
\text { closest } \\
\text { university }\end{array}$ & $\begin{array}{l}\text { Laurentian } \\
\text { not closest } \\
\text { university }\end{array}$ \\
\hline $\begin{array}{l}\text { Program } \\
\text { perceived as } \\
\text { widely available }\end{array}$ & $88.5 \%$ & $52.5 \%$ \\
\hline $\begin{array}{l}\text { Program } \\
\text { perceived as } \\
\text { not widely } \\
\text { available }\end{array}$ & $78.5 \%$ & \\
\hline
\end{tabular}

choose a university, other than Laurentian, as first choice. Similarly, in each model the importance a student places upon university acceptance likelihood (Models 1,2 and 4) or program acceptance likelihood (Model 3) is a strong and consistent discriminating factor; with those who place high importance on university or program admission likelihood preferring Laurentian as first choice.

Location suitability (excluding costs) offers discriminating ability in all four models as well. The change in signs reflects the fact that those students who place importance on this factor will always tend to prefer their closest university. Thus, for Models $I$ and 3 where Laurentian is the closest university, there exists a strong preference to attend Laurentian, but for Models 2 and 4 where Laurentian is not the closest university, there is a strong preference to attend another University (presumably the closest).

Many other factors have strong discriminating ability but not in all four models. For example, class size importance has a very strong, unidirectional discriminating ability in Model 2, less so in Models 3 and 4, but is not useful in predicting first choice university for those students seeking a widely available program whose closest university is Laurentian. Several factors are unique to one of the four models.

Given the situation, the importance an individual placed on the 18 evaluative criteria, and the respondent's sex, age, marital status, high school grade average and language spoken, the appropriate situation model was employed to predict whether the respondent chose Laurentian or any other university as his/her first preference university. Table 6 shows for each situation, the percent of respondents' choices correctly predicted. Thus for situation 1, 89.2 percent of 
respondents were correctly predicted as choosing Laurentian as first choice or as choosing any other university as first choice.

The results presented in Table 6 are upwardly biased because the same cases have been used to test as to build each of the discriminant models. Due to the small sample size a split sample technique was not possible. The U-method (Lachenbruch and Mickey, 1978) was considered to be too time consuming and not warranted by the level of the data, however, a rough method of validation was used by utilizing those cases with one or more missing values as a validation group. Note, cases involving missing data were not employed in the development of the models themselves. The missing case validation method must by its very nature give very conservative results. Whilst the model cannot be considered as precise (Wentz, 1972), nevertheless the results, presented as Table 7 are quite encouraging with the model performing significantly better than chance. Table 7 presents the prediction accuracy results when all cases involving missing data are analyzed. When cases involving more than two pieces of missing data are excluded from the analysis results improve measurably.

Given the nature of the task, that is to predict which university will be selected as first preference from a list of the candidate's top two or three universities to which he/she has applied, the models as a whole show excellent predictive ability. This predictive ability is even more astonishing when one considers that all of these students regardless of their first preference university actually ended up enrolling at Laurentian.

\section{IMPLICATIONS FOR EDUCATIONAL ADMINISTRATORS}

University administrators are often concerned with ways by which they can effectively increase the number of student applications for enrollment. Such administrators are concerned with understanding not only the benefits students seek from a university education, but also the evaluative factors students employ in determining preferred universities to which to apply and in ultimately selecting a preferred university to attend.

This paper has shown that two situational factors (university proximity and program availability) have significant impacts upon the importance of various evaluative factors employed by students.

In assessing the implications of these findings for their marketing efforts, university management must first decide into which sectors their programs fall; this is best done by measuring students perceptions of a given program's availability, and the proportion of students in that program for which that university is the closest one. Table 8 shows such an analysis for Laurentian. Of course, if the management wish to attract a new segment of the student market then this segment should determine into which situation the program is classified.

University managements should of course measure the most significant choice factors for their particular university. Knowledge of these evaluative factors can be 
TABLE 8

An Analysis of the Current Situational Position of Laurentian's Programs

\begin{tabular}{|c|c|c|}
\hline \multirow{2}{*}{$\begin{array}{l}\text { Program Choice } \\
\text { Availability }\end{array}$} & \multicolumn{2}{|c|}{ University Choice Proximity } \\
\hline & $\begin{array}{l}\text { Laurentian } \\
\text { closest } \\
\text { universityl }\end{array}$ & $\begin{array}{l}\text { Laurentian } \\
\text { not closest } \\
\text { university2 }\end{array}$ \\
\hline $\begin{array}{l}\text { Program } \\
\text { perceived } \\
\text { as widely } \\
\text { available3 }\end{array}$ & $\begin{array}{l}\text {-Arts } \\
\text {-Sciences } \\
\text { - Commerce } \\
\text {-Teacher } \\
\quad \text { Education }\end{array}$ & $\begin{array}{c}\text {-Engineering } \\
\text {-Physical } \\
\text { Education }\end{array}$ \\
\hline $\begin{array}{l}\text { Program } \\
\text { perceived as } \\
\text { not widely } \\
\text { available4 }\end{array}$ & -Nursing & $\begin{array}{l}\text {-Sports Admin- } \\
\text { istration } \\
\text {-Translation } \\
\text {-Social Work }\end{array}$ \\
\hline
\end{tabular}

Notes: 1 Percentage of students living closest to Laurentian is above average for these programs.

2 Percentage of students 1 iving closest to Laurentian is below average for these programs.

3 Programs whose perceived availability is more than the average for all programs.

4 Programs whose perceived availability is less than the average for all programs.

used in the following ways:

1. To design effective promotional packages for existing programs and for the university as a whole.

2. Also for existing programs, knowledge of the evaluative criteria together with student or prospective student ratings of the university on the pertinent evaluative factors can be used as an indicator of where the university should consider instituting program or university design changes.

3. The evaluative criteria can also be used to indicate what types of new programs are most likely to prove successful in the marketplace and how such new programs should be promoted.

Using the results from the Laurentian study, many implications can be reached concerning the approach Laurentian should follow in its attempts to increase student applications. Examples of these implications are presented and discussed in the following section. 


\section{SELECTED IMPLICATIONS FOR LAURENTIAN}

Designing Effective Promotional Packages for Laurentian's Existing Programs and for the University as a whole

In designing a promotional package, Laurentian, like all universities, has a choice of either promoting its areas of recognized strength or attempting to alter prospective student views concerning its weaknesses.

In particular, within each of the four situations previously described, Laurentian should promote factors of high importance to the student for which Laurentian has a competitive advantage or at least does not have a particular competitive disadvantage vis-à-vis other universities offering this program. This material would be supplemented by either ( 1 ) information which stresses the factors where Laurentian shows demonstrated relative strength, or by (2) information which attempts to alter the perception of prospective students on those factors which are most likely to lead them to go elsewhere.

Applying this thinking to those prospective students who are applying for one of Laurentian's widely available programs and who live in close proximity to Laurentian, indicates that Laurentian should promote the fact that it offers programs in both English and French, and either (1) promote factors of relative strength such as its location suitability, class size, university size, cost of attending and possibly the higher chance of being granted admission (though this may turn away some of the better qualified students), and/or (2) attempt to alter the perception of prospective students on those factors which are most likely to lead them to go elsewhere, in this case attempt to alter the view of Laurentian as a university having a low overall and program academic quality and reputation.

Table 9 summarizes the factors which should be promoted by Laurentian in each of the four situations previously described. It is based on a comparison of Tables 2 and 4.

In some cases, promotional material may be developed for individual programs or for a group of similar programs which stress the relevant criteria. In other circumstances, it may not be possible to target communications in such a specific way. In such a case, it may be advisable to portray typical students, for example an Arts student, who lives close to Laurentian, who endorses the applicable situational criteria and a Sports Administration student, who lives at some distance from Laurentian, who endorses the criteria applicable to that situation.

\section{Using Knowledge of the Evaluative Criteria together with Student or Prospective} Student Ratings of the University on the Pertinent Evaluative Factors to Indicate where Laurentian Should Consider Instituting Program or University Design Changes

The information presented in this paper indicates that students, excluding those who do not live close to Laurentian and who are applying for admission to a program that is perceived as not widely available, hold, on average, relatively poor views of the academic quality and reputation of such programs and of Laurentian as a whole. Other evidence clearly indicates that Laurentian's market share of 
TABLE 9

Factors To Be Emphasized in Laurentian's Program and University Promotions

\begin{tabular}{|c|c|c|c|c|}
\hline & \multicolumn{4}{|c|}{ Situational Groups } \\
\hline & \multicolumn{2}{|c|}{$\begin{array}{l}\text { Program perceived as } \\
\text { widely available }\end{array}$} & \multicolumn{2}{|c|}{$\begin{array}{l}\text { Program perceived as } \\
\text { not widely available }\end{array}$} \\
\hline PROMOTE & $\begin{array}{l}\text { Laurentian } \\
\text { closest }\end{array}$ & $\begin{array}{l}\text { Laurentian } \\
\text { not closest }\end{array}$ & $\begin{array}{l}\text { Laurentian } \\
\text { closest }\end{array}$ & $\begin{array}{l}\text { Laurentian } \\
\text { not closest }\end{array}$ \\
\hline $\begin{array}{l}\text { Factors of high } \\
\text { importancel to all } \\
\text { students for which } \\
\text { Laurentian has a } \\
\text { competitive } \\
\text { advantage }\end{array}$ & None & None & None & None \\
\hline $\begin{array}{l}\text { Factors of high } \\
\text { importancel to all } \\
\text { students for which } \\
\text { Laurentian is at } \\
\text { least not at a } \\
\text { competitive } \\
\text { disadvantage }\end{array}$ & $\begin{array}{l}\text {-Instruction- } \\
\text { al language }\end{array}$ & -None & $\begin{array}{r}\text {-Instruction- } \\
\text { al language }\end{array}$ & $\begin{array}{l}\text {-Program } \\
\text { quality \& } \\
\text { reputation } \\
\text { - Instruct- } \\
\text { ional lang- } \\
\text { uage }\end{array}$ \\
\hline $\begin{array}{l}\text { PLUS, EITHER } \\
\text { PROMOTE }\end{array}$ & & & & \\
\hline $\begin{array}{l}\text { Factors where } \\
\text { Laurentian shows } \\
\text { relative strength } \\
\text { vis-a-vis other } \\
\text { universities }\end{array}$ & $\begin{array}{l}\text {-Location } \\
\text { suitability } \\
\text {-Class size } \\
\text {-Univ. size } \\
\text {-Likelihood of } \\
\text { admission } \\
\text {-Cost of } \\
\text { attending }\end{array}$ & $\begin{array}{l}\text {-Class size } \\
\text {-Residence } \\
\text { availability } \\
\text { \& quality } \\
\text {-Univ. size } \\
\text {-Likelihood of } \\
\text { admission }\end{array}$ & $\begin{array}{l}\text {-Location } \\
\text { suitability } \\
\text {-Class size } \\
\text {-Univ. size } \\
\text {-Likelihood of } \\
\text { univ. admis. } \\
\text {-Cost of } \\
\text { attending }\end{array}$ & $\begin{array}{l}\text {-Class size } \\
\text {-Univ. size } \\
\text {-Residence } \\
\text { avail. and } \\
\text { quality }\end{array}$ \\
\hline $\begin{array}{l}\text { OR ATTEMPT TO } \\
\text { ALTER PERSPECTIVES } \\
\text { OF PROSPECTIVE } \\
\text { STUDENTS ON } \\
\text { Factors which are } \\
\text { most likely to } \\
\text { lead them to apply } \\
\text { el sewhere }\end{array}$ & $\begin{array}{l}\text {-0verall univ. } \\
\text { academic } \\
\text { quality and } \\
\text { reputation } \\
\text {-Program } \\
\text { quality \& } \\
\text { reputation }\end{array}$ & $\begin{array}{l}\text {-Overall univ. } \\
\text { academic } \\
\text { quality and } \\
\text { reputation } \\
\text {-Location } \\
\text { suitability } \\
\text {-Language of } \\
\text { instruction }\end{array}$ & $\begin{array}{l}\text {-0verall univ. } \\
\text { academic } \\
\text { quality and } \\
\text { reputation } \\
\text { - Program } \\
\text { quality \& } \\
\text { reputation }\end{array}$ & $\begin{array}{l}\text {-0verall univ. } \\
\text { academic } \\
\text { quality and } \\
\text { reputation }\end{array}$ \\
\hline
\end{tabular}

NOTES: 1 To be classified as a factor of high importance to all students for a given situation, the factor must be ranked within the top 5 factors in Tables 2 and 4.

students who live closest to Laurentian is extremely low for programs that are perceived as widely available. Additionally, on a program by program basis there is considerable evidence to suggest a high correlation between a Laurentian program's share of the local market and students evaluation of that program's academic quality and reputation.

These findings suggest that the perceived quality of Laurentian's programs may have more to do with their perceived uniqueness than with the actual quality of such programs and that it might be advantageous for Laurentian, even within the liberal Arts and Sciences areas, to structure and promote its programs as somewhat different than those of other universities. The concept of widely available Arts and Science programs may be a provincial government objective but may pose a 
difficult selling job for a relatively new regional university like Laurentian. The restructuring and promotion of existing programs should be much less costly than the introduction of totally new programs.

\section{LIMITATIONS OF THE STUDY REPORTED HERE}

This study of students who are already attending a higher educational institution suffers from problems of both recall and cognitive dissonance. However, the practical difficulties of conducting longitudinal studies with a sample of high school students led the researchers to adopt this more limited research project at the current time.

Another serious limitation is that only students at Laurentian University were included in the current survey. Whilst the results are obviously biased, nevertheless they provide an indication of the results that might be obtained elsewhere. Furthermore, the analytical framework provided in this paper should prove of use to all educational administrators.

\section{FINDING GENERALIZABILITY}

Some of the findings presented in this report concerning the importance of various evaluative factors as assessed by students attending Laurentian are likely to prove generalizable. In particular, those findings discussed under the section the "Absolute Importance of the Evaluative Factors for Each Situational Context" are expected to hold for all universities. For example, students who perceive their desired program of studies as not widely available place more importance on a wide range of factors including, amongst others, the academic quality of and university reputation for that program.

On the other hand, findings concerning the relative importance of various evaluative factors are unlikely to be generalizable; nor are most of the findings related to specific factor importance in the student's choice of a first preference university. Indeed, as each university needs to develop its own unique market position, in order to be successful, one might argue that generalized findings are not useful. Rather it is the generalizability of this analytical process employed in this paper that is potentially useful to university administrators.

The framework developed in this paper provides a useful addition to the general planning framework discussed elsewhere (see Church and Gillingham, 1983b and Doyle and Lynch, 1976).

\section{CONCLUSION}

In conclusion, the situational matrix improves the analytical framework for understanding the students decision process for selecting a preferred university.

By understanding the variations in this decision process within various situational contexts, university administrators should be better equipped to develop improved promotional and structural strategies to attract either more or better students to their universities. 


\section{FOOTNOTES}

1. There are 15 universities in Ontario. Students are permitted to apply to no more than three of these universities and must indicate to an all-university application processing center their first, second and third program-university choices.

2. This finding must be viewed somewhat skeptically as the comparison group of "those not living closest to Laurentian and choosing any other university as first choice" may not be particularly representative of those attending another university which is their closest university.

\section{REFERENCES}

Belk, R.W. Situational Variables and Consumer Behavior. Journal of Consumer Research, 1974, 2 (December), 157-164.

Church, J.H. \& Gillingham D.W. Student Benefit Segments. School of Commerce and Administration, Laurentian University, Discussion Paper, (1983a).

Church, J.H. \& Gillingham D.W. Student Choice and University Marketing Planning. School of Commerce and Administration, Laurentian University, Discussion Paper, (1983b).

Dickson, P.R. Person-Situation: Segmentation's Missing Link. Journal of Marketing, 1982, (Fall), 56-64.

Doyle, P. \& Lynch, J. Long Range Planning for Universities. Long Range Planning, 1976, (December), 39-48.

Lachenbruch, P.A. \& Mickey, M.R. Estimation of Error Rates in Discriminant Analysis. Technometrics, 1978, 10 (February), 1-11.

Lynch, J. \& Hooley, G. The University Choice Process. EAARM-MEG Proceedings, 1980, (March), 222-246.

Punj, G.N. \& Staelin, R. The Choice Process for Graduate Business Schools. Journal of Marketing Research, 1978, 15 (Nov.), 588-598.

Sandell, R.C. Effects of Attitudinal and Situational Factors on Reported Choice Behavior. Journal of Marketing Research, 1968, 5 (August), 405-408.

Saunders, J.A. \& Lancaster, G.A. The Student Selection Process: A Model of Student Courses in Higher Education. University of Bradford Discussion Paper, (1980).

Vaughn, R., Pitlik, J. \& Hansotia, B. Understanding University Choice a Multi-Attribute Approach, in K. Hunk (Ed.). Advances in Consumer Research, Ann Arbor: Association for Consumer Research, 1981, 26-31.

Watts, A.G. Diversity and Choice in Higher Education, London: Routledge and Kegan Paul, 1972.

Wentz, W.B., Marketing Research: Management and Methods, New York: Harper and Row, 1972. 